\title{
Geology and mineral resources of Phalamdada-Dhuwakot section of west-central Nepal, Lesser Himalaya
}

*Arjun Bhattarai and Kabiraj Paudyal

Central Department of Geology, Tribhuvan University, Kritipur, Kathmandu Nepal

\begin{abstract}
Geological mapping was carried out along the Phalamdanda-Dhuwakot section of west-central Nepal in the Lesser Himalaya. The aim of geological mapping was to prospect the metallic mineral resources in the area especially to assess the geological control of mineralization as prognostic mapping and study the genesis of mineralization. The area has developed low-grade metamorphic rocks of the Nawakot Group. Geological rock units like the Kuncha Formation, Fagfog Quartzite, Dandagaon Phyllite, Nourpul Formation and Dhading Dolomite are mapped in the area. Jal Bhanjyang Thrust carries the more older rocks of the Nourpul Formation over the Dhading Dolomite. The area is highly deformed as indicated by presence of folds. Outliers of Fagfog Quartzite and Dhading Dolomite are developed at the core part of the syncline. Phalamdada iron and Anbu Khaireni as well as Dharapani copper are the major metallic deposits reported in the area. Both deposits are considered as the syngenetic in nature.
\end{abstract}

Key words: Geology, Lesser Himalaya, mineral deposits, syngenetic

Received: 9 April 2018

Accepted: 17 June 2018

\section{INTRODUCTION}

In Nepal, the Lesser Himalaya is highly promising for metallic minerals mainly like iron, copper, lead, zinc, cobalt, nickel, tin, tungsten, molybdenum, gold, uranium, and rare metals etc. Present study area is a small part of autochthonous succession in west-central Nepal, Lesser Himalaya. It consists of low-grade metamorphic rocks like slate, phyllite, quartzite, dolomite, and metasandstone. The area has many occurrences of some potential mineral resources. Copper and iron deposits are the potential mineral resources so far studied in the area. The study area lies between the latitudes of $27^{\circ} 52^{\prime} 30^{\prime \prime} \mathrm{N}$ to $27^{\circ} 59^{\prime} 30^{\prime \prime} \mathrm{N}$ and longitudes between $84^{\circ} 23^{\prime} 30^{\prime \prime} \mathrm{E}$ to $84^{\circ} 33^{\prime} 50^{\prime \prime} \mathrm{E}$ (Fig. 1). This paper is focused in the detailed geological mapping in 1:25000 scale around the Phalamdada-Dhuwakot area with the aim to assess the metallic mineral resources in terms of their geological control, genesis and preliminary reserves estimation. For that, efforts were made to spend more time in the field mapping taking traverses through several closely spaced routes and river sections. Representative samples of rocks and minerals were collected for microscopic observation and geochemical analysis. Geological mapping was done at the both banks of the Marsyandi River and correlated with the previous works (Paudyal and Paudel 2011a, 2011b, 2011c; Paudyal 2012; Paudyal et al. 2012; Paudyal and Paudel 2013; Paudyal 2014). The study area is the western continuity of the regional geological map of Stöcklin and Bhattarai (1977) and Stöcklin (1980). Many mineral deposits of the area have been reported by Department of Mines and Geology (Sharma 1990; Talalov 1972; DMG 2004). Adjacent area of present study was also explored by the team of geologists of the mineral

*Corresponding author

Email: bhattaraiarjun123@gmail.com (A. Bhattarai)

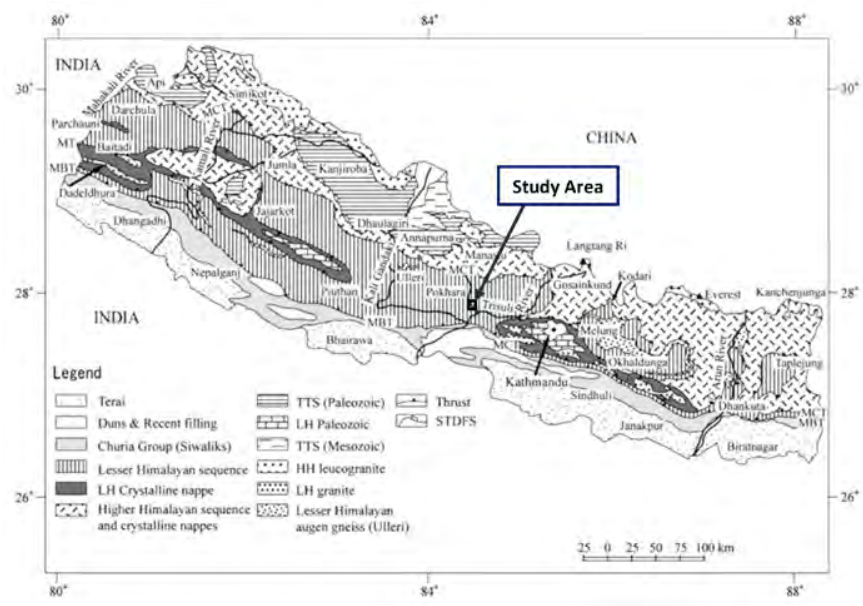

Fig. 1: Location map of the study area on geological map of Nepal (Upreti and Le Fort 1999).

exploration project from the Department of Mines and Geology, Nepal (Stocklin and Bhattarai 1977; Stöcklin 1980) and by United Nations (1993). Later, Paudyal (2014) has studied the occurrences and geological control of mineralization in Bandipur-Gondrang area of Tanahun District and adjacent area. Present work is the continuity of this work towards west.

\section{GEOLOGICAL SETTING AND LITHOSTRATIGRAPHY}

Detailed geological mapping was carried out along the Phalamdada (Tanahun District) and Dhuwakot (Gorkha District) in 1:25,000. Geological units like the Kuncha Formation, Fagfog Quartzite, Dandagaon Phyllite, Nourpul Formation with three members (viz. the Purebensi Quartzite, Labdi Khola Member and the Bandipur Slate) and the Dhading Dolomite from stratigraphic older to younger are mapped in the area (Fig. 2). Following these units along the strikes, 
geological map along with cross-section was prepared (Fig. 3).

The northern part of the study area such as Abu-Khaireni, Thimure, Abuwa, Bhorle, Kaushilatar, Ghartigau, Biruwatar, etc. are covered with the Kuncha Formation, the oldest rock unit of the Lesser Himalaya. It is a succession of phyllite and metasandstone with subordinates of quartzite and dolomite. Lower part of the unit consists of grey, fine-to coarsegrained metasandstone and greenish grey phyllite in various proportions. The weathering of rocks in the area is remarkable red. This red soil has been mined as the raw material for the clinker. Upper part of the unit consists of the calcareous greenish grey phyllite, thin beds of reddish grey dolomite, and grey, greenish grey, thick-bedded metasandstone. It covers the Yankot, Thimure, Phedi Bajar and Namjun area. The dolomite contains sub-rounded to angular clasts of quartzite, slate, metasandstone, phyllite, and dolomite up to $10 \mathrm{~cm}$ in diameter (Fig. 4). The Kuncha Formation forms comparatively smooth ridges with gentle spurs and valley slopes. The contact of the Kuncha Formation and the overlying Fagfog Quartzite is sharp.

The Fagfog Quartzite is well exposed at Thapathan, eastern part from Jhirbas and southern part of Abu Khaireni (Fig. 3). It consists of thin-to thick-bedded, medium-to coarse-grained, yellowish white quartzite with thin-parting of the grey, finegrained pelitic phyllite. The beds are usually parallel and continuous to several meters. It consists of about $50 \mathrm{~cm}$ thick band of hematite in between Jhirubas and Dharapani, shows the hydrothermal origin. Due to influence of hematite, along contact region, the quartzite is of pink color. The polymetallic minerals such as hematite, magnetite, pyrite etc. are observed within black phyllite near Marsyandi Hydropower dam site. The lower succession of the Fagfog Quartzite is rich in sedimentary structures such as both parallel and cross laminations and wave ripples (Fig. 5). The thickness of this unit is about $400 \mathrm{~m}$ which is underlain by the Dandagaon Phyllite sharply.

The Dandagaon Phyllite is extensively distributed south and southeast of the Marsyandi River, along the Abu-KhaireniDumre road section and around the villages Yagchok, Ghimiredada, Nayagau, and Dharapani areas. The lower part of the Dandagaon Phyllite comprises black pelitic phyllite, calcareous psammitic phyllite and dirty grey quartzite. This is followed by a thick succession of non-calcareous grey, bluish grey and dark grey laminated soapy phyllite with some intercalations of sandy phyllite and dark grey metasandstones. Occasionally, thin layers of grey dolomites are found within the succession. The upper part of the unit consists of alternating bands of well-foliated black phyllite and ferruginous metasandstones in various proportion. The lithology as a whole reflects darker tone in outcrop than as in the Kuncha Formation which makes the main difference between these two formations. The dark grey phyllite of the Dandagaon Phyllite is often strongly deformed and exhibit crenulations. The rocks of Nourpul Formation sharply underlies the Dandagaon Phyllite.

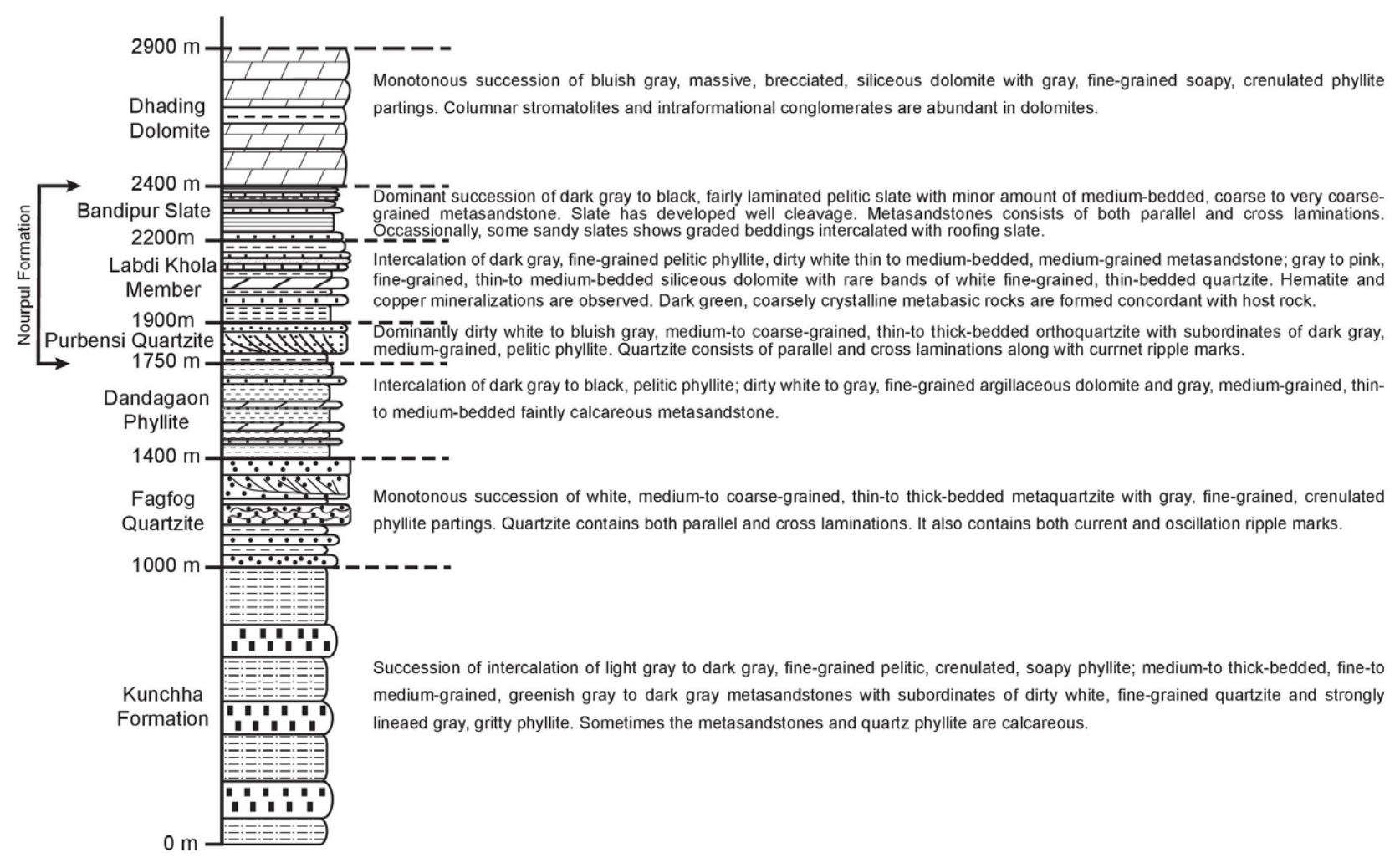

Fig. 2: Generalized stratigraphic column of the study area. 


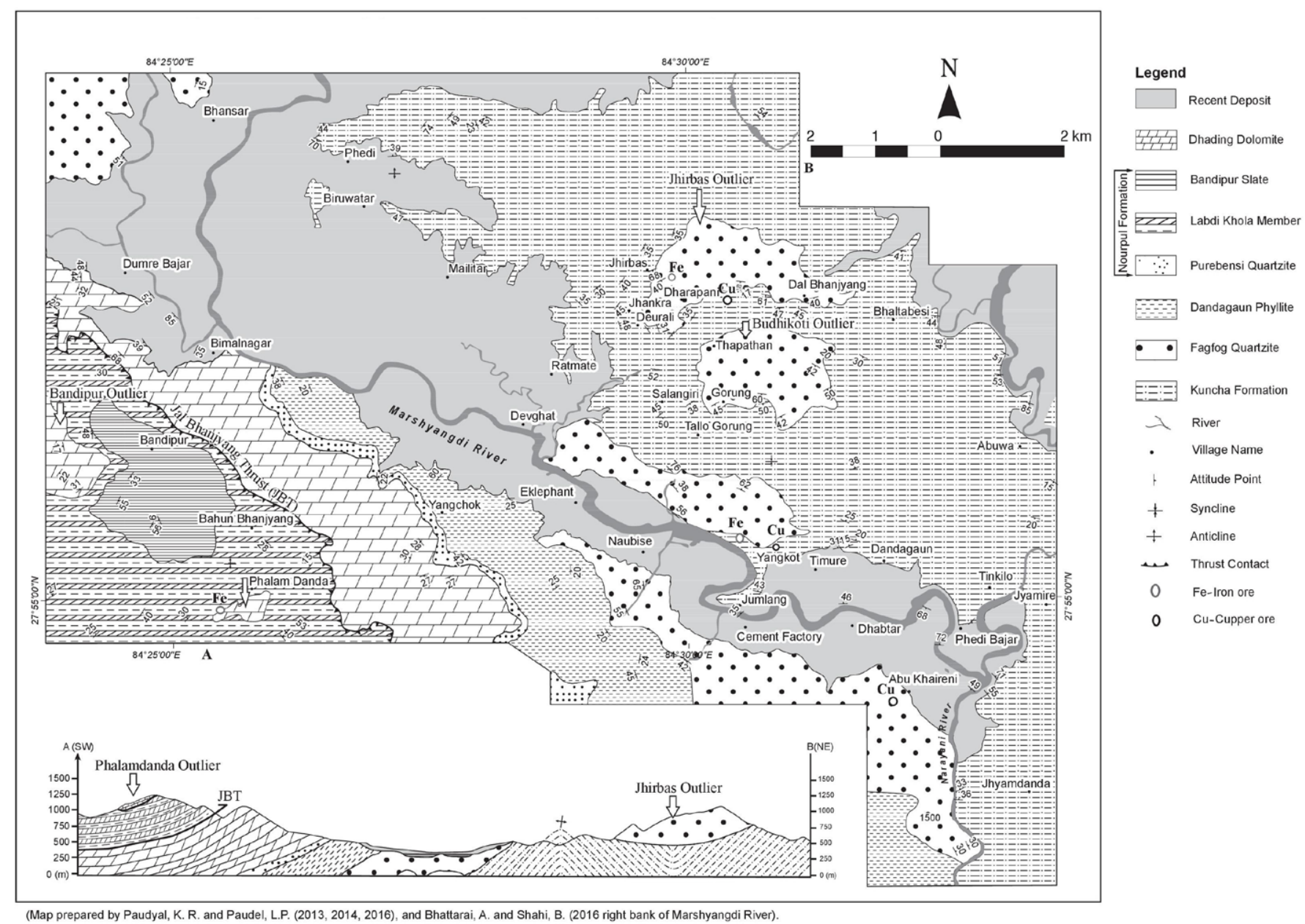

Fig. 3: Geological map of Anbu Khaireni-Bandipur area, west central Nepal.

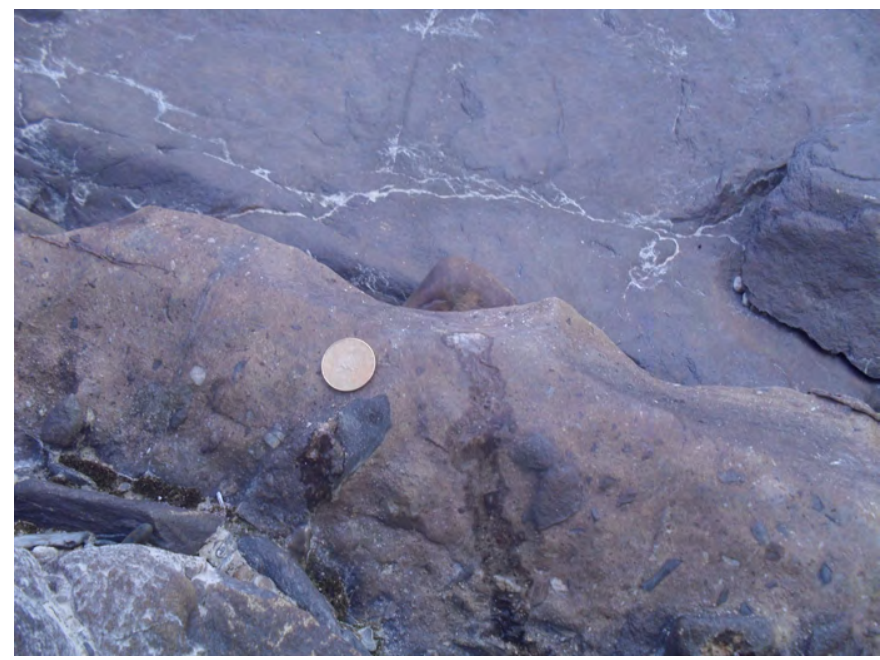

Fig. 4: Field photograph showing the conglomerate.

The Nourpul Formation is exposed extensively in southern part of the study area. It is a succession of varied type of lithology like grey phyllite, grey-green slate, green-purplered shale, grey metasandstone, pink dolomite, pink, grey, dirty white quartzite etc. Based on the dominant lithological characteristics, the rocks of this unit can be further mapped

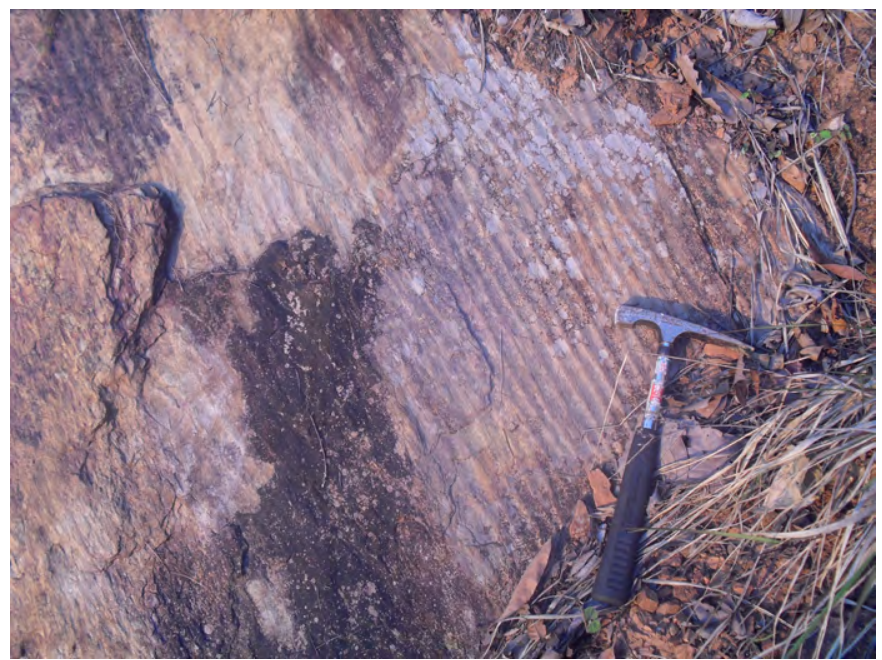

Fig. 5: The ripple marks observed on the Fagfog Quartzite.

into three members in the area as the Purebensi Quartzite, the Labdi Khola Member and the Bandipur Slate from bottom to top respectively. The Purebensi Quartzite is lithologically distinct and acts as a marker succession in the area. It is well distributed in the Kotgaun, Samastipur, Bardada, and Kalchok areas (Fig. 2). This unit is dominated by dirty white to ash 
grey, parallel and cross-laminated quartzite $(80 \%)$ intercalated with grey, green-grey, crenulated, and coarse-grained pelitic phyllite (20\%). It consists of abundant current and oscillation ripples and occasionally the cross-beddings. Parallel beddings are very common in these rocks.

The Labdi Khola Member comprises the succession of intercalation of slate, phyllite and metasandstone with frequent interlayering of siliceous, pink to cream colored dolomite and faintly calcareous quartzite. Lower part of the succession consists of greenish grey metasandstone, brown pelitic phyllite, grey psammitic phyllite with rare bands of grey, thin-bedded, silicious dolomite and thin-bedded dirty white quartzite. The middle part consists of grey, greenish grey, green, pelitic phyllite and grey to greenish grey metasandstone in about equal proportion. The upper part of the succession consists of sandy phyllite. In Bandipur area, the Labdi Khola Member has transitional contact with the overlying Bandipur Slate.

Bandipur Slate is well-developed at Bandipur and its adjacent areas locally. The rock succession consists of the monotonous succession of grey, faintly-laminated slates with subordinates of grey, coarse-to very coarse-grained, medium - bedded metasandstones. The thickness of individual sheets of the slates is measured in the range of millimeter to few centimeters. The metasandstones are laminated with distinct cross-beddings. It is mapped as the top most unit of the Nourpul Formation. The total thickness of the unit is $>200 \mathrm{~m}$ and its contact with overlying Dhading Dolomite is sharp. In the study area, Dhading Dolomite is exposed in two places: above the Purebensi Quartzite due to the Bhangeri Thrust and in isolated pockets as outliers in southern part of the study area. The Dhading Dolomite is a monotonous succession of bluish grey, thin-to thick-bedded, siliceous dolomite with grey, fine-grained, crenulated pelitic phyllite as partings. Dolomite consists of poorly preserved algal mats and well-developed columnar stromatolites (Fig. 6). Grey to dirty white quartzite is occasionally associated within the succession. Weathered outcrops display elephant skin appearance, honey-comb structures and some leaching and dissolution features like stalactites and stalagmites with many cavernous surfaces. A prominent Bhangeri Thrust carries the older Labdi Khola Member of the Nourpul Formation on its stratigraphic top position. There is an isolated outlier of the Dhading Dolomite at SE of the Bandipur at Phalamdanda area. Thickness of the Dhading Dolomite is not uniform in the area; it is about $300 \mathrm{~m}$ in Bandipur.

\section{GEOLOGICAL STRUCTURES}

At the right bank of the Marsyandi River, rocks are highly folded forming anticline and syncline structures. The core of syncline has developed two outliers which are named as the Budikoti Outlier and Jhirbas Outlier. Similar case is also found in the Bandipur-Phalamdada area where two outliers of the Dhading Dolomite over the Nourpul Formation are mapped. These are named as the Bandipur Outlier and the

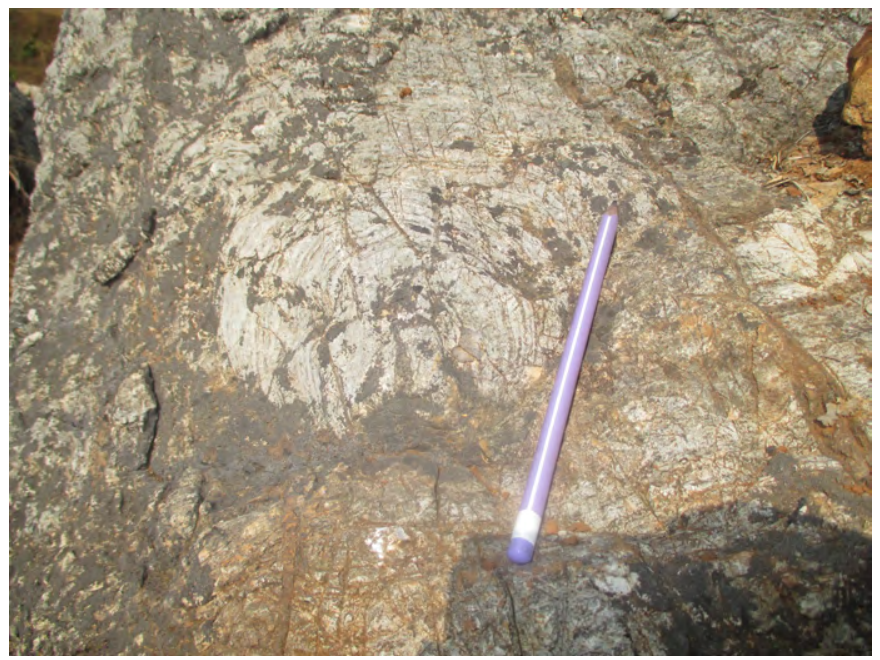

Fig. 6: The columnar stromatolite on the Dhading Dolomite.

Phalamdada Outlier. In the Bimalnagar-Dumre section, there is direct contact between the Fagfog Quartzite and the Dhading Dolomite representing erosional unconformity. At the southwest corner of the map (Fig. 3), the Jal Bhanjyang Thrust (JBT) carries the more older rocks of the Nourpul Formation over the Dhading Dolomite. Presence of fault-related features like breccia, striations and slickensides support the existence of fault in the region.

\section{MINERAL RESOURCES: OCCURRENCES AND GEOLOGICAL CONTROL}

The area consists of both metallic and industrial mineral deposits. However, only the metallic deposits are dealt here. The metallic minerals mainly copper and iron were observed with some poly-metallic mineral deposits in the present study area. Iron ore are noticed within the rocks of the Fagfog Quartzite (e.g. near Jhirbas and near hydropower dam of Marsyandi River) and at the contact between the Nourpul Formation and the Dhading Dolomite at Phalamdada area (Fig. 2). The thickness of the iron band in Jhirbas area is $50 \mathrm{~cm}$ in average and strike length is $60 \mathrm{~m}$.

Iron ore are conformed by their higher specific gravity, iron-rusting color and metallic lustre. The iron ore of the Phalamdada area is identified as the limonite. Physical properties of limonite are: rusting brown color, medium specific gravity, light brown to red streak, spongy appearance, hackly fracture, metallic lustre and opaques. It does not react with hydrochloric acid. Iron ores found in other areas are the hematite, magnetite and pyrite in association. Similarly, the occurrences of copper ores are found in the rocks of the Fagfog Quartzite at the upper reaches of the Abu Khaireni and at the contact of the Kuncha Formation and the Fagfog Quartzite at Dharapani area. Presence of copper deposits are well indicated by the colorful leaching of azurite (blue) and malachite (green) in the outcrops. Based on the present prognostic mapping, only the iron deposit of the Phalamdada area can be considered as sub-economic or potential deposit and the study has been focused and described in detail in the following section. 


\section{Phalamdada iron prospect}

It is located at longitude $27^{0} 54^{\prime} 55^{\prime \prime} \mathrm{E}$ and latitude $84^{\circ} 25^{\prime} 11^{\prime \prime} \mathrm{N}$ (elevation $999 \mathrm{~m}$ ) in the vicinity of Bandipur. Stratigraphically, it lies in between the underlying metasediments (phyllite and metasandstone of the Nourpul Formation) and the overlying dolomite of the Dhading Dolomite. The extension of iron ore is controlled by the geological contact of these two rock formations (Figs. 7-8). The thickness of iron deposit is not uniform throughout the ring of the outlier.

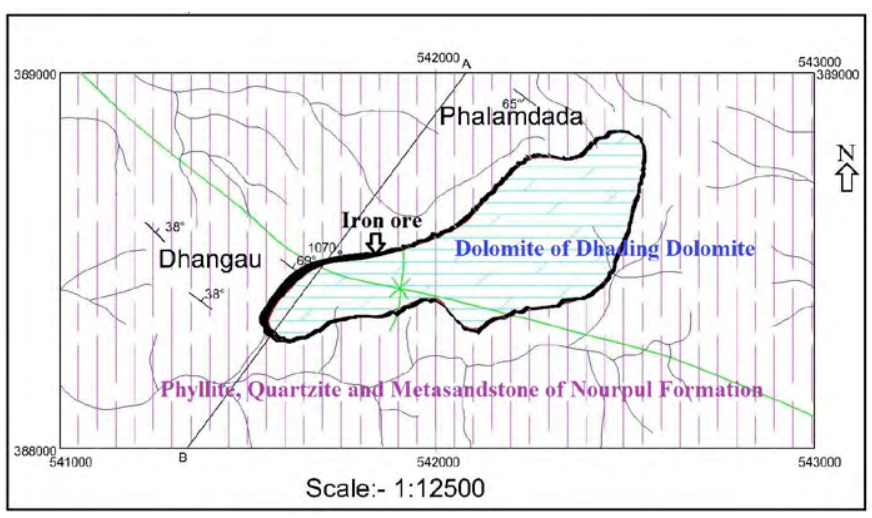

Fig. 7: Geological map of the Phalamdanda iron deposits.

\section{Chemical analysis of the iron ore}

The grab samples were collected in between $84^{\circ} 25^{\prime} 11^{\prime \prime}$ to $84^{\circ} 25^{\prime} 15^{\prime \prime} \mathrm{E}$ and $27^{0} 54^{\prime} 54^{\prime \prime}$ to $27^{\circ} 54^{\prime} 55^{\prime \prime} \mathrm{N}$. Chemical test was carried out in the laboratory of Shivam Cement Ltd. Hetauda-21, Makawanpur by the x-Ray diffraction method. The results of chemical analysis is presented in Table 1.

Table 1: Chemical analysis of iron ore (oxides with their percentages)

\begin{tabular}{|l|l|l|l|l|l|}
\hline Sample no. & $\mathbf{S i O}_{2}$ & $\mathbf{A l}_{2} \mathbf{O}_{3}$ & $\mathbf{F e}_{2} \mathbf{O}_{3}$ & $\mathbf{C a O}$ & $\mathbf{M g O}$ \\
\hline $\mathbf{I}-1$ & 76.62 & 9.81 & 4.00 & 2.15 & 5.45 \\
\hline $\mathbf{I - 2}$ & 22.99 & 9.81 & 51.50 & 2.15 & 2.89 \\
\hline $\mathbf{I - 3}$ & 24.26 & 9.81 & 41.50 & 2.15 & 5.15 \\
\hline $\mathbf{I}-4$ & 40.22 & 9.81 & 21.00 & 2.15 & 6.12 \\
\hline $\mathbf{I - 5}$ & 20.77 & 8.02 & 56.66 & 3.04 & 5.46 \\
\hline $\mathbf{I - 6}$ & 31.73 & 9.13 & 42.60 & 3.00 & 4.98 \\
\hline $\mathbf{I - 7}$ & 48.83 & 7.66 & 24.16 & 2.28 & 3.66 \\
\hline $\mathbf{I - 8}$ & 16.34 & 8.78 & 4.50 & 2.91 & 36.4 \\
\hline $\mathbf{I - 9}$ & 38.66 & 9.28 & 38.73 & 1.98 & 4.21 \\
\hline $\mathbf{I - 1 0}$ & 55.65 & 7.72 & 25.66 & 3.31 & 1.94 \\
\hline $\mathbf{I - 1 1}$ & 8.39 & 4.76 & 72.30 & 2.68 & 2.48 \\
\hline
\end{tabular}

\section{Gross reserve estimation of the Phalamdada iron deposit}

Strike length of the strata $=2000 \mathrm{~m}$, thickness of ore (avg.) $=$ $5 \mathrm{~m}$, mining depth $=30 \mathrm{~m}$ (assumed on the basis of geological cross-section, geological map and topography).

Volume $=2000 \times 5 \times 30$ cubic meter $=3,00,000$ cubic meters

Tonnage $=$ Volume $\times$ Density

$$
=3,00,000 \times 5.5=16,50,000 \text { tons. }
$$

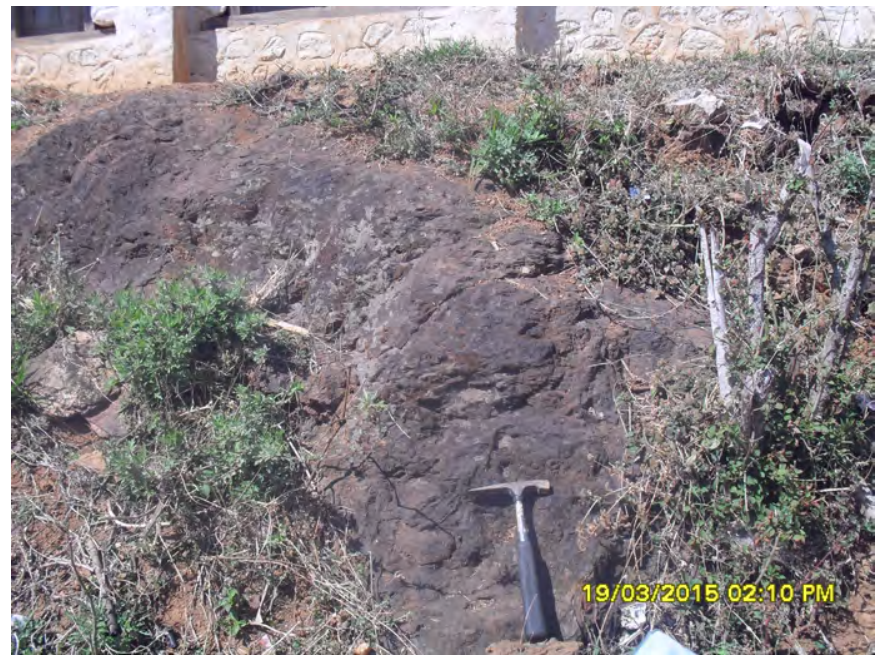

Fig. 8: Outcrop showing the iron ore in the Phalmadanda.

\section{DISCUSSIONS}

Geological mapping in the area shows that there is continuity of stratigraphic succession as mapped by Paudyal and Paudel (2011) in the western parts of the present study. The most remarkable is the unconformity between the Fagfog Quartzite and the Dhading Dolomite. Along strike mapping shows that there is missing of both the Dandagaon Phyllite and the Nourpul Formation in the Bimalnagar-Dumre area. The exact contact between the Fagfog Quartzite and the Nourpul Formation has covered by the terraces of the Marsyandi valley. This has blocked the opportunity to observe the unconformity contact. Another most remarkable feature is the presence of four outliers within a small area. Two outliers of the Fagfog Quartzite are mapped in the Jirbas and Budhikot areas while the other two outliers of the Dhading Dolomite are observed in the Bandipur-Phalamdada area. These outliers are developed in the core of the synclinal structures.

Present study area consists of iron and copper as metallic minerals. The contact of the Kuncha Formation and the Fagfog Quartzite consists of copper deposit in the Dharapani and Yankot areas which lie in the northern part of the studied area and near to Abu Khaireni. (Fig. 2). The copper mineralization has occurred in the phyllite of the Kuncha Formation. The genesis of copper mineralization therefore, can be linked with the synsedimentary hydrothermal origin. To assess the quantity and quality further exploration is necessary.

The ferruginous quartzite has noticed in the Fagfog Quartzite at Jhirbas and Yankot villages. However, the iron deposit of Phalamdada is found at the contact of the Dhading Dolomite and Labdi Khola Member of the Nourpul Formation. The iron is mineralized as the intercaltion with the host phyllite. This indicates that the mineralization is syngenetic in nature. The iron deposit of the Phalamdada is noticed as the sub economic.

\section{CONCLUSIONS}

The rocks of the Nawakot Group are exposed in the Phalamdada-Dhuwakot section of west central Nepal. 
Geological units as the Kuncha Formation, Fagfog Quartzite, Dandagaon Phyllite, Nourpul Formation with three members and the Dhading Dolomite has been mapped respectively from older to younger stratigraphy. An unconformity contact has been mapped between the Fagfog Quartzite and the Dhading Dolomite along the Bimalnagar-Dumre section. Four outliers has been mapped at the cores of syclinal structures. Two of them are mapped as the outliers of Fagfog Quartzite in the left bank side of the Marsyandi and the other two outliers of Dhading Dolomite are mapped at the Bandipur-Phalamdada area. Jalbhanjyang Thrust has brought the more older rock succession of the Nourpul Formation over the Dhading Dolomite. Occurences of both copper and iron mineralization are mapped in the area. Copper has mineralized in the rocks of the Fagfog Quartzite at Anbu-Khareni, Yangkot and Dharapani areas. Also, the copper is mineralized in the phyllite of the Kuncha Formation at Yangkot village. Similarly, iron has been mineralized in two stratigraphic position: one in the rocks of the Fagfog Quartzite (at Yangkot and Jhirbas areas) and another at the geological contact between the Nourpul Formation and the Dhading Dolomite (at Phalamdada area). Both the iron and copper are syngenetic in origin. Iron of Phalamdada area is sub-economic while the copper deposits and iron deposits of other areas need further studies for detail exploration.

\section{REFERENCES}

DMG 2004. Mineral Resources of Nepal. Department of Mines and Geology, Ministry of Industry, Government of Nepal, $154 \mathrm{p}$.

Paudyal, K.R., and Paudel, L.P., 2011a. Geological setting and lithostratigraphy of the Lesser Himalaya in the MuglingBanspani area, central Nepal. Jour. Nepal Geol. Soc., v. 42, pp. 51-64.

Paudyal, K.R., and Paudel, L.P., 2011b. Re-interpretation of the stratigraphy of the Nawakot Complex in the Mugling area between Dasdhunga and Ghumaune, central Nepal. Jour. Strat.
Asso. Nepal, v. 7, pp. 23-32.

Paudyal, K.R., Pokharel, T., and Paudel, L.P., 2011c. Petrography and illite crystallinity of the Lesser Himalayan metasediments, Gorkha-Narayangarh section, central Nepal. Bull. Dept. Geol., Tribhuvan University, Kathmandu, Nepal, v. 14, pp. 67-76.

Paudyal, K.R., Adhikari, L.B., Maharjan, N., and Paudel, L.P., 2012. Geological setting and lithostratigraphy of Bandipur-Gondrang area of Lesser Himalaya, central Nepal. Bull. Dept. Geol., Tribhuvan University, Kathmandu, Nepal, v. 15, pp. 49-6.

Paudyal, K.R., 2012. Depositional environment of the Lesser Himalayan rocks in the Mugling-Bandipur area, central Nepal. Jour. Nepal Geol. Soc., v. 44, pp. 89-98.

Paudyal, K.R., and Paudel, L.P., 2013. Geological study and root zone interpretation of the Kahun Klippe, Tanahun, central Nepal. Him. Geol., v. 34(2), pp. 93-106.

Paudyal, K.R., 2014. Occurrences of mineral resources in BandipurGondrang area of Tanahun district, central Nepal, Lesser Himalaya. Jour. Sci. Engg., Khwopa Engineering College, v. 2, pp. 4-35.

Sharma, C.K., 1990. Geology of Nepal and adjoining countries; Sangeeta Publication, Educational Enterprises, Kathmandu, $470 \mathrm{p}$.

Stöcklin, J., 1980. Geology of Nepal and its regional frame. Jour. Geol. Soc. London, v. 137, pp. 1-34.

Stöcklin, J., and Bhattarai, K.D., 1977. Geology of Kathmandu Area and Central Mahabharat Range Nepal. Department of Mines and Geology Kathmandu, Nepal, 86 p.

Talalov, V.A., 1972. Main features of magmatism and metallogeny of the Nepalese Himalayas. In: Jest, C. (Ed.), Ecologie et géologie de l'Himalaya 268. C.N.R.S. Paris, Volume Science de la Terre Coll. Int, Ed. Cent. Nat. Rech. Sci. Paris, pp. 409-430.

United Nations, 1993. Geology and Mineral Resources of Nepal, v. 9. UN Economic and Social Commission for Asia and the Pacific (ESCAP) and Department of Mines and Geology (DMG), pp. 107.

Upreti, B.N., and Le Fort, P., 1999. Lesser Himalayan Crystalline Nappes of Nepal: Problem of their origin. In Mcfarlane, A., Quade, J., and Sorkhabi, R., (Eds.): Himalaya and Tibet: mountain roots to tops. Geol. Soc. America (Sp. Paper), pp. 225-238. 